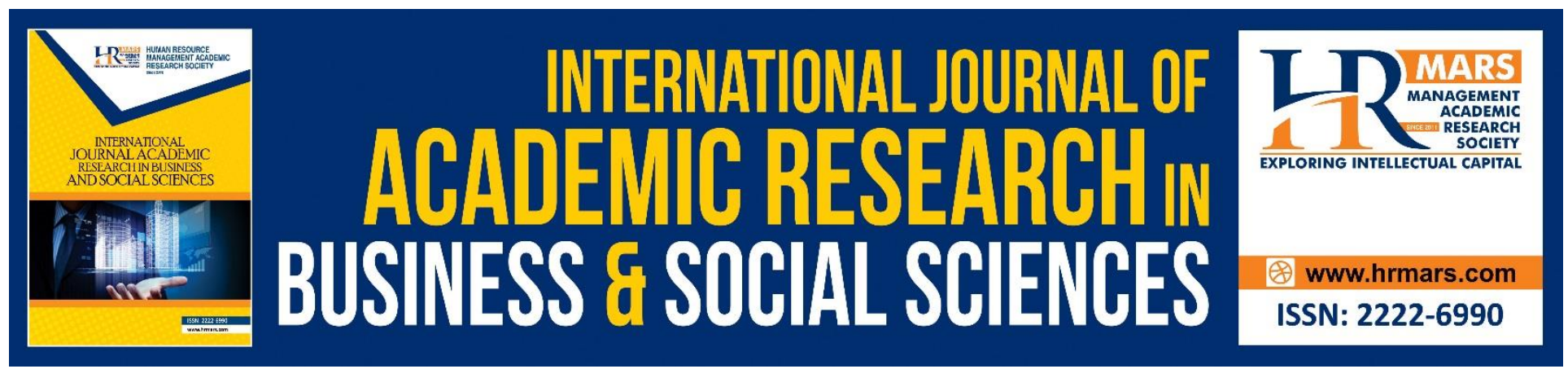

\title{
Malay Land Ownership in Pahang Until 1957
}

\section{Nor Hidayah Dzul-Kifli, Khairi Ariffin}

To Link this Article: http://dx.doi.org/10.6007/IJARBSS/v10-i6/7464

DOI:10.6007/IJARBSS/v10-i6/7464

Received: 21 April 2020, Revised: 23 May 2020, Accepted: 12 June 2020

Published Online: 09 July 2020

In-Text Citation: (Dzul-Kifli \& Ariffin, 2020)

To Cite this Article: Dzul-Kifli, N. H., \& Ariffin, K. (2020). Malay Land Ownership in Pahang Until 1957. International Journal of Academic Research in Business and Social Sciences, 10(6), 947-958.

\section{Copyright: (c) 2020 The Author(s)}

Published by Human Resource Management Academic Research Society (www.hrmars.com)

This article is published under the Creative Commons Attribution (CC BY 4.0) license. Anyone may reproduce, distribute, translate and create derivative works of this article (for both commercial and non-commercial purposes), subject to full attribution to the original publication and authors. The full terms of this license may be seen at: $\underline{\text { http://creativecommons.org/licences/by/4.0/legalcode }}$

Vol. 10, No. 6, 2020, Pg. 947 - 958

Full Terms \& Conditions of access and use can be found at http://hrmars.com/index.php/pages/detail/publication-ethics 


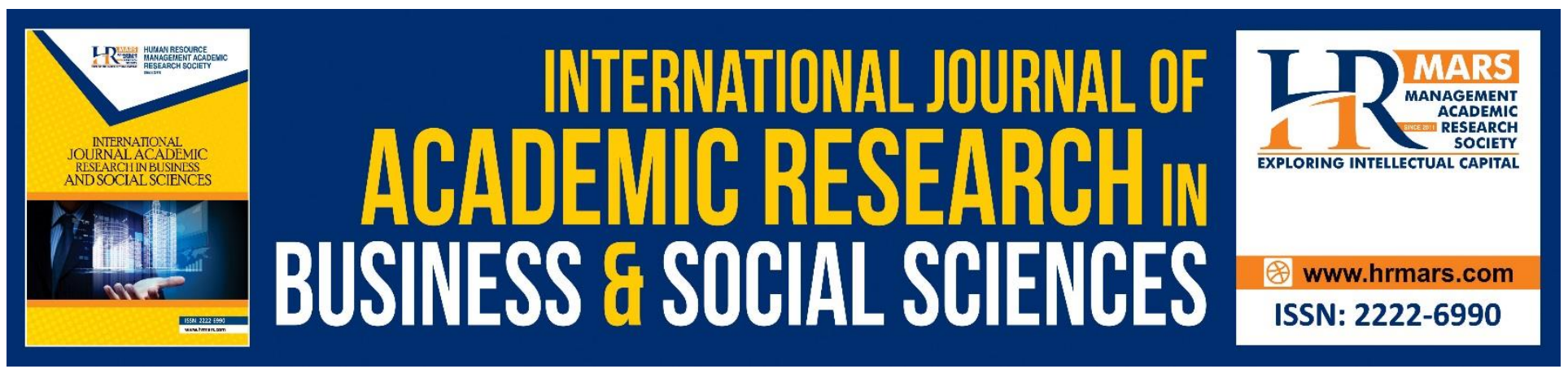

\title{
Malay Land Ownership in Pahang Until 1957
}

\author{
Nor Hidayah Dzul-Kifli ${ }^{1}$, Khairi Ariffin ${ }^{2}$ \\ Department of History, Sultan Idris Education University, 35900 Tanjong Malim, Perak \\ Email: dayahdzulkifli94@gmail.com
}

\begin{abstract}
The system of land ownership was introduced to the Malay community through a new system of land laws by the British. This study uses qualitative methods by analyzing the documents available in the National Archives of Malaysia such as Straits Settlements, Federated Malay States, Annual Report, District Office Report and State Secretary files. The findings show that land ownership introduced by the British succeeded in eradicating the system of slavery practiced in Pahang. The new land legal system also facilitated the people to improve their economic standard of living without having to rely on the Sultan and his nobility. The findings of the study are also important to show the role of the Sultan in the Traditional Land System until the emergence of a new system of land laws introduced by the British in Pahang to ensure that the Malays gained their independence as free slaves. In addition, through the land administration system, the nobles who had previously relied heavily on slavery in land enterprises, could no longer do so under British rule after the introduction of land laws. In conclusion, the community is able to cultivate its own land and reap the benefits of the plantation to ensure its survival without having to pay tax to the growers.
\end{abstract}

Keywords: Land Ownership, Slavery, New Land Law System, Malay, Pahang.

\section{Introduction}

The history of land development in the British age has been carried out, but most of them only tried and touched the two main sectors of development which are related to agricultural activities and the formation of settlements as Preliminary indication of an area that is owned. The development of a custom system, a land ownership can only be recognised as evident by any effort or work considered to be regarded by or developing the land. (SUHAKAM, 2015) According to Gullick (1965), under the administration of the traditional Malay sultanate, people are allowed to work on land provided they pay tax to the Sultan or the district speaker appointed by the King. Since the people in the Malay states are not crowded compared to the land area that is still vast and many, the land has no exchange value as each family produces food only enough for each other. (Hagen \& Wolfgang, 1940) Hence, the question of owning land as property does not arise because land is only required to provide a living requirement.

Although the ownership of the land in the Malay Customs system receives various criticism and views from scholars, but something accepted by the degree is that the land is basic and is related to humanitarian development on it. In the context of law and land administration, whether custom 
or colonial, land is seen as a development tool and economic growth. In the Colonial land regulation system, land is a foundation of development for humans, such regulations ensure a fair division of land. Therefore, any land law not only emphasizes the problem of ownership, but it includes the problems of the usage, rights and responsibilities of the owner and its users. (Wilson, 1954) The British saw economic potential in the Malay states that were so encouraging to find that they were facing a customary land ownership system that was not suited to the British capitalist economic approach.

\section{The Background}

Before British arrival to Pahang, the administration was used as a traditional system but after the arrival of the British, the administration began to be transformed into Western administrative patterns. This statement is evidenced by the passage,

\section{"The letter dated $24^{\text {th }}$ August 1888 marks the end of Sultan Ahmad's rule in Pahang. From then on, political power began to shift from the sultan to the British government." (Gopinath, 1993)}

The traditional administration in Pahang is not far different from other states in Malaya. The community is divided into certain classes, which are from high to low according to the community's plywood. (Gullick, 1965) Traditional Malay administrators consist of sultans, speakers of the Royal and non-Royal Descent and Penghulu. (Gullick, 1965) Sultan was a government class that had the highest position and was a symbol of a state. He was responsible for leading the central administration at the state level, performing justice and managing ties with other external states. He was also a powerful ground in his state and directed the local speaker to manage it. The land ownership system in the traditional simplified community as the local residents often moved, so local speakers used a collective means of land ownership as there were many vacant land. (Muttalib, 1972) A land belongs to the king and a person who requires the land to give a letter to the king. (Low, Dissertation on Penang and Province Wellesley) Maxwell explained that:

"Indeed, only a small portion of the land is the real property of the country and probably only the best rice cultivation land obtained directly from the king by deed." (Maxwell, 1884)

That passage showed that the land in Pahang before the emergence of a small British was the right of the country. (Muttalib, 1972) However, only agricultural land for paddy cultivation is not interrupted by the Sultan because the paddy crop is an important for tax. The Sultan also reserves the right to transfer the land to any person who wills whether to the district head nor his/her person on the ground where there is no white or broken letter indicating a land belongs. However, after the Civil War was completed in Pahang, the land title continued to change. This change in title is due to the sultan's handover of land to those who have contributed to him in the war. (Muttalib, 1972) 
INTERNATIONAL JOURNAL OF ACADEMIC RESEARCH IN BUSINESS AND SOCIAL SCIENCES

Vol. 10, No. 6, June, 2020, E-ISSN: 2222-6990 @ 2020 HRMARS

"... the sultan shows his ownership of the land by giving concessions at will to foreign capitalists such as China Europe and the Arab entrepreneurs from Johor." (Muttalib, 1972)

"It is these heads who de facto own the land, in the sense of taxdeductible rights that are often arbitrary. The chiefs in addition had their own agricultural lands where the whole produce was their right as the workers consisting of slaves did not have the right to distribute the produce other than the right to obtain the basic necessities of food and clothing from their master." (Muttalib, 1972)

The above passage describes that the right of a servant on the land being employed is only as an employee and the outcome of the belongs also is food and clothing obtained from their master in a very minimal scale. This suggests that the landlord is monopolize the right of a servant as to their heart so that they continue to work on agricultural land.

\section{Problem Statement}

The land ownership system is an initiative that is developed and implemented by the British in Pahang to remove the customary land ownership system used in the Malay traditional land system. In an effort to remove this customary land ownership system, the dependency attitude among the people and the Sultan is also deleted. The Sultan of Pahang would like to see a developed economic development for Pahang, but its effort was not encouraging due to the granting of land concessions to outsiders. (Malaysian Historical Society, 2005) Various problems occurred such as suppression, murder and theft occurring in the state administration so as to give the British a chance to bring in the resident system. The British opportunity to enter Pahang occurred when treaty in 1887 with Sultan Ahmad was affected by the assassination of the British. (Colonial Office, 1888) However, since British intervention occurs in the administration system, the problem of land ownership has provided the facilities for the residents in Pahang to conduct the economy in order to continue its survival.

\section{Methodology}

Data analysis has been conducted using qualitative research methods with the design of document analysis and manuscripts using National Archives material research. Studies have been made in the National Archives by making references and primary source analysis such as files. Analyzed files such as the Pahang State Government Secretary's file and the British colonial record file. The use of second resources is also used to support this study by researching at the Sultan Idris Library and the National Public Library. For the final move, data assessment and findings were made in analytical and the interpretation of hermeneutic. Review of previous studies is also used as a source of instructions related to this study by former researchers. The material of the second source is used as a research material and analysis by the researchers to see the study coherent such as books, journals and theses.

\section{Discussions}

In the effort of the British to get the trust of Sultan Ahmad al-Mu'azzam Shah, more commonly known as Sultan Ahmad was difficult due to various issues and challenges that arise in the system of 
government. However, cooperation between Johor and Pahang led the Sultan Ahmad to sign a treaty with the British with the British condition of implementing the Reign in Pahang "similar to Johor". (Colonial Office, 1886) The results taken by Sultan Ahmad were driven by political developments in Johor. However, the agreement between Sultan Ahmad and the British is still not completely in the administration system, this is because the Sultan still has the privilege of concession in accordance with the sixth clause in Covenants 1887. (Yusoff \& Gopinath, 1992) He can also rent the land and provide concessions without the consent of the Governor except to the non-English Europeans.

However, in the agreement in 1887 stated that if the security of the British agent was affected or killed, Pahang had to accept the resident system. (Colonial Office, 1888) The British opportunity to enter Pahang became a reality when Go Hui, a British people were killed in February 1888. The murder led to the introduction of the British rule which once concluded the independence of Sultan Ahmad. Sultan Ahmad was concerned with the appointment of a Resident, however, the Sultan of Johor was sent by the Governor Smith to advise Sultan Ahmad to agree to accept the British adviser. (Colonial Office, 1888). Due to the situation in Perak and Selangor which were peaceful after the presence of the resident, this situation convinced him to receive it. However, Sultan Ahmad also sent a letter to the British by saying that the British resident John Pickersgill Rodger sent to Pahang could carry out administrative duties and to assert a retention question Rights of privileges.

The emergence of the resident system which began in Pahang brought changes in the administration system, especially the land ownership system. It is a guarantee for the people in Pahang to do any job due to the availability of the Land law system introduced to give the following facilities to improve the standard of living of the people in Pahang who had previously relied on To the speaker and the Sultan to work on any job.

The British introduced a 'proprietary system' to provide opportunities for the people in Pahang to acquire their own land to work on any agricultural and livestock. (British Adviser's Office Selangor, 1954). Through this proprietary system, it is not aware of the community in Pahang regardless of the system of slavery and also the land tax system imposed by the magnifying on them. In addition, through this land ownership system, the community will be able to develop their own economy so as not to be bound by the customary ownership system practiced previously to achieve the British capital economic approach over Community in Pahang.

\section{Land Ownership before Arrival British}

The land administration before British intervention in Pahang was placed under the jurisdiction of the Sultan and the district speaker only. If they want someone to have it, they will give them the land. The district speaker, which has its own land, will surely use slave services to work on agriculture on their land. For the forest which was not operated, the land was a non-faceted land. When Chinese or European people want the land, they will have to pay concession money or give a division of revenue to the district chief. Land administration before the year 1889 is managed and implemented by the Sultan and the district speaker. The land administration in Pahang also has no land ownership system which is special for the local residents as the Sultan and the district speaker will pass the land according to any person. Prior to the correspondence, the mode of land ownership before the 19th 
century is based on those residing in a land. (Muttalib, 1972) In the traditional administrative system, the land is divided into two, namely the land of life and dead land.

Before the arrival of the British to Pahang, the Malay community did not experience any complexity in the land question. The use of land before the 19th century, only caters to living needs, which are gardening, paddy or the forest materials. (Abdullah, 1985) This has led to the traditional Malay community not to require a specialized and institutional ownership system and land administration. (Anderson, 1965) According to the laws of the land surveyed by Maxwell, the land is divided into two parts, i.e. living land and dead land. (Maxwell, 1884) With regard to land ownership, customary land laws make it clear that a person's right to land depends on anyone exploring, redeeming, cleaning and cultivating the land provided that the land is not occupied by anyone else and that the settler must be a Muslim. (Maxwell, 1884)

\section{The Dead Land}

Dead land is a land that has been abandoned and have no one tree or plant remains on the land. A person who opened the dead land became a living land with no right to sell his land. (Muttalib, 1972) Dead land can also be classified when the land is not occupied and no sign of the land is used, then the land is called as the dead land. The dead land also includes forest lands or land which have been done but left to become a forest. (Winstedt, 1928) The Paddy is categorized as a dead land when a land has not been done for three years.

\section{The Dead of Life / Tanah Hidup}

Living Land is a land that is owned by a person either by way of his or her means of planting. If the land has signs that imply still being used or operated by a crop, it is known to be the land of life and this land will not be tampered with by anyone as long as the crops need to be done. (Winstedt, 1928) The division of living land among them involves village land, land or paddy fields, Huma land or plantation. The village land is planted with fruit trees and the right of ownership on it is happening during the land occupied, as long as it is planted with fruit trees and paddy fields. The land is runny and is inspired by Paddy. Proportion's right to occur as long as the land is occupied or in the next three years. Next, Huma land or farm. The hill lands commonly used for cultivation, permanent crops. The rights of ownership of this land occur as long as the land is occupied which is usually for one season.

Each person is free to choose and open the land he wills but provided that the proceeds from the cultivation undertaken on the land should be given partly to the district chief. (Muttalib, 1972) Land is essentially regarded as a property belonging to the Sultan and he has the right to collect land revenue, tax revenue and to sell obsolete land as well as having the right to award land to anyone who is liked by him. (Muttalib, 1972) Based on this old land system, the ownership of land is more dependent on the concept of effort. For those who are working on the land, so the people who work in that will acquire the land. In addition, the District speaker is also authorized to confer land under its custody to its followers or loyal people. However, the land recognition was not exceeding the land area which was able to be awarded by the Sultan in the form of concession ever made. Land owners are also charged rentals on land owned. The magnifying speakers will make the proceeds on the rent 
INTERNATIONAL JOURNAL OF ACADEMIC RESEARCH IN BUSINESS AND SOCIAL SCIENCES

Vol. 10, No. 6, June, 2020, E-ISSN: 2222-6990 @ 2020 HRMARS

of land. This is because, the speaker can no longer collect any collection of land rentals after the new laws are introduced by the British. This can be proved further with the screenshot below.

"... In Pahang, land revenue has formed an item of our receipts almost from the first. The people have thus become accustomed to the payment of rent upon the land they occupy, and the headmen are gradually becoming acquainted with their customs..."(Federated Malay States, 1896)

This indicates that the magnifying in each district will no longer have the power to collect any land rental under his administration instead of their duties taken over by British officers assigned in each district for example F. Belfield in the town district. This was due to the new administrative system introduced by the British resident in Pahang. The Royal Malay State Administration has already existed but the administration's relationship with the indirect people is founded on the principle of land ownership rights that are ultimately in the king's hands. (Wong, 1975) He rejected the fact that the people had to work with the authority or the king and had to surrender some of their proceeds to the Sultan. On the other hand, all the work of the people or energy done and payments or contributions given by the people to the Sultan are showing only the loyalty. So, this indicates that the land ownership system before a reform brought by the British, people are much easier to receive because it is a way for them to demonstrate allegiance to the Sultan. However, since British appearance, the rights of land ownership introduced by the British had taught the Malay community in Pahang to be no longer dependent on the Sultan and the speaker and the landlord.

\section{Malay Traditional Land Administration System}

This Malay traditional land system is more focused on traditional land customs laws where the concept of land titles is not so stressed. So, people do not have the land officially as enshrined in a letter or a white form of black say that a land is in his absence. Because of the reign undertaken by the Sultan of Pahang before it came to the British in the absolute discretion, the king was considered a person who had Daulat and the place of the people's dependency. The King as the ultimate power in the traditional age is the symbol of unity and the focus of the faithful people's loyalty in various forms of loyalty, payment, grant, presentation or energy service. (David Wong, 1975) Although all these forms of loyalty are not necessarily fulfilled by each citizen, it exists in the Malay community value system and to be part of some that reflects the government's greatness. Due to the traditional government system, there is no one body devoted to administering matters relating to land and the land is the ownership of the king in terms of practically difficult to be identified. Swettenham argued that

\section{"... The concept of a land ownership belongs to the king is a wrong assumption." (Cowan, 1964)}

Instead, he pointed out that the Malays did not have any land ownership system. It is so because, they are free to open any land without paying any payment. According to Swettenham, only the king or speaker is trying to show their power by imposing various taxes. (Wong, 1975) Customary law of land the community is associated with Islamic law, therefore, as a Sultan who governs the country, 
all land belongs to God and Sultan just as administrators only. (Abdullah, 1985) So, people can open and make use of land including the right to have items to be taken from that land. As the Sultan as an administrator to all land, he has the right to collect any tax on the citizens. However, if the people do not pay certain taxes then the Sultan has the power to seize their land. The concept of Sultan has power over all the land to be vague especially in the final quarter of the 19th century when the political system in the Malay states becomes loose, including in the town district. This situation is attributed to the economic significance that triggers the shift in power among the rulers. The Division's power to the Magnifier directly affects the integrity of the Sultan itself. When the economic importance of overcoming the purity of customs, the political unrest ending with the chaos of the Sultan's allocation to the regional rulers also eased the Sultan's power.

Although the Sultan has the power to place any order for an example, 'area $A$ is belonging to the Speaker', but the area is dependent on good relations between the sultans and the magnitude. If the Sultan does not consent to the speaker, the title and all efforts of the land or area shall continue to change ownership to the next person. In the final quarter of 19th century, the position of Sultan as the highest power would no longer have the ability to claim any area held by the magnitude. In essence, in many instances, people are much more than the Sultan himself. The separation of powers to the speaker causes the Sultan to not be entitled to the ownership of land controlled by the majority. (Wong, 1975) However, the position and appointment of the Sultan became secured after the British introduced its administration system after the year 1874. By assuming the fact that all the land belongs to the Sultan, the British then made some land law reform. That is why, when the Sultan was dominated by the British then directly, under the law introduced by the British, all land was declared to be a government.

\section{British Land Administration System}

The introduction of the English administration system in Pahang began when the resident system dominated the state in 1889. This statement was also explained in Syair Malaya, the stories of the Pahang War and Johor Bahru:

"Kepada hijrah Rasul yang indah

Seribu Tigaratus Sembilan jumlah

Masuklah Residen sekarang sudah

Sudah bertukar adat perintah"

(Monographs of history and Culture of Pahang, 1982)

The influx of British residents in Pahang had resulted in a change in the government and administrative system which was previously Pahang using traditional systems. The British dominance, which is the importance of the economy, has become a major issue to their administration. A customary land ownership system as previously practiced by the Malays is certainly not suited to the British-free economic system. Therefore, this system is modified in line with the needs of the economic system of capitalism. Under the resident system, the Sultan ceased to have power in administration but a full-authority resident and responsible for introducing several changes including the land ownership system. (Abdullah, 1985) 
The Western administration system is conducted to replace the traditional administration system. By 1 July 1889, British administration began to dominate the administration of Pahang which resulted in several changes in land administration in the Pahang district. (Census of Pahang, 1891) Pahang is divided into six administrative districts namely Pekan, Kuala Pahang, Kuantan, Rompin, Temerloh, and Ulu Pahang. Each district is under the administration of an European state tax retrievers. (Annual Report Pahang, 1889) Therefore, the position of Penghulu's traditions as tax collector is impaired for being replaced by the British tax collector. Due to the concept of the Sultan before British arrivals represented a government, so all the land of a state was the government's title and when the Sultan was successfully dominated by the British, the land administration also moved to new administration. Thus, began changes to the Land law system. The changes that occur in this land administration system affect the Government and economic system in Pahang.

In September 1890, John Pickersgill Rodger had left Pahang because of his long vacation. So, the Pahang government headquarters in the town was placed under the care of F. Belfield until Hugh Clifford was taken to become the regent of the British resident of Pahang from 24 November 1890. (Adil, 1972) In the state Legislative Assembly which was convened for the third time on 11 December 1890, Hugh Clifford had submitted a land bill that was owned by the Malay community since his domestic generations. The laws and regulations of the land were implemented in January 1891 and set the land charged for rent or tax. (Adil, 1972) Researchers are thought through the changes made by the British in the land administration have completed a bondage system in the people in Pahang. With the availability of the boundary system or the land ownership system to an individual, and indirectly entitles a person to own land. In addition, the land ownership system by the people, causing them to be free from their local speakers as previously they are powerful in putting a job to the people. In addition, the power of local speakers over the people began to be lost and as well as the sources of income that were previously obtained from tax collection from the people. This statement can be proved further with the statement of the Aminudin Abdul Karim stating:

"The leaders of Pahang who had lived in the tradition of slavery and who had been hereditary tax collectors lost their power and income." (Karim, 2012 page 55-56)

The British replaced their income with allowances, but the local speakers did not agree with the granting of this allowance until the occurrence of the British. (Karim, 2012) Based on article from the second Capitel: Invigorate of Pahang's history from 1889-1952, the British had also been intervened in the question of bondage and the collar system by introducing new laws. (Karim, 2012) It was further strengthened through the Sultan of Pahang's directive tradition of 1800-1930, which said that the position was stake especially due to two sensitive issues of bondage and forced labor. (Yusoff \& Gopinath, 1992) In the traditional government system, these two factors are the measure of individual wealth in communities and the introduction of laws negatively affect Sultan and his nobles.

\section{British Land Law}

Before the arrival of the British to Pahang, the administration conducted was traditional administration of the customary land law but after the resident system and enforcement of the general Land regulations introduced through the Torrens system, the Land Law Custom terminated. 
INTERNATIONAL JOURNAL OF ACADEMIC RESEARCH IN BUSINESS AND SOCIAL SCIENCES

Vol. 10, No. 6, June, 2020, E-ISSN: 2222-6990 @ 2020 HRMARS

The administration began to change by introducing various new land regulations. For the Federated Malay States (FMS), English law is generally beginning to take effect through the resident system which began in Perak through the Pangkor Treaty in 1874. In particular, the land law based on the Torrens system was first implemented by the British beginning in Selangor in 1882 through the General Land regulations. The British implemented the Torrens system through several levels:

1. The general rules of the land are uniform and enforceable under the law in Selangor (1882), Negeri Sembilan (1887), Pahang (1888) dan Perak (1897).

2. Uniform registration rules are in place at Selangor (1891), Perak dan Pahang (1897) dan Negeri Sembilan (1898).

3. The FMS 1911 land enactment and the FMS 1911 property registration enactment came into force and repealed all previous state law.

4. The Land Act 1928 repealed both previous enactments. (Fathi, 2016)

\section{Land Ownership under the Administration}

The question of land ownership of the Penghulu in Pahang in the years of 1940 and before it is not hard to obtain or request permission to own land from the government as required on other government officials and this is subject to the General Order regulations. (Abdullah, 1985) The flexibilities are given for thinking that Penghulu is a respected person and leader in one Mukim. However, the eligibility of owning land is due to the consideration of their respective provincial officers. (No. 2246/48 Pahang Secretariat File, SUK Pahang) This regulation was supported by the Sultan of Pahang on the advice of the Council of rulers. (No. 659/49 Pahang Secretariat File, SUK Pahang) However, since the beginning of the new land regulations brought by the British, ownership documents were introduced. Documents obtained from Pahang Secretariat File to prove the registered rights of a land owner. It also contains all important things and information related to land such as grants or leases, state level, land plan, area, lot number and others.

\section{Acknowledgement}

Appreciation to my supervisor, Associate Professor Dr Khairi Bin Ariffin for giving me the wonderful opportunity to complete my Master thesis under his supervision, it is truly an honor. Thank you for all advice, ideas, moral support and patience in guiding me through this project.

\section{Corresponding Author}

Nor Hidayah Dzul-Kifli

Department of History, Sultan Idris Education University

35900 Tanjong Malim, Perak

Email: dayahdzulkifli94@gmail.com 
INTERNATIONAL JOURNAL OF ACADEMIC RESEARCH IN BUSINESS AND SOCIAL SCIENCES

Vol. 10, No. 6, June, 2020, E-ISSN: 2222-6990 @ 2020 HRMARS

\section{References}

\section{Document}

British Adviser's office Selangor. (1954). A General Survey of New Villages. Kuala Lumpur: Government Press.

Census of Pahang. (1891). Straits Settlement Government Gazette, 1892. Kuala Lumpur: National Archives of Malaysia.

Colonial Office 273/142. (1886). Granville to Meade, 18 Mei 1886. Kuala Lumpur: National Archives of Malaysia.

Colonial Office 273/154. (1888). Smith to Sultan Ahmad, 29 Jun 1888. Kuala Lumpur: National Archives of Malaysia.

Colonial Office 273/154. (1888). Smith to Sultan Ahmad, 21 November 1888. Kuala Lumpur: National Archives of Malaysia.

Federated Malay States. (1890). Supplement to the Pahang Government Gazette, Pahang Administration Report for 1890. Kuala Lumpur: F.M.S Government Printing Office.

Federated Malay States. (1896). Supplement to the Pahang Government Gazette, Pahang Administration Report for 1896. Kuala Lumpur: F.M.S Government Printing Office.

Pahang Secretariat File No. 659/49. Kuantan: Pahang State Secretary's Office.

Pahang Secretariat File No. 2246/48. Kuantan: Pahang State Secretary's Office.

\section{Journal Article}

Cowan, C. D. (1951). Sir Frank Swettenham's Perak Journal 1874-1876" Journal of the Malaysian Branch of the Royal Asiatic Society, 24(4), 81-148.

Maxwell, W. E. (1884). Law and Custom of the Malays with reference to the Tenure of Land, Journal of Straits Branch Royal Asiatic Society,13, 7-46.

Winstedt, R. O. (1928). Kedah Law, Journal of the Malaysian Branch of the Royal Asiatic Society, 6 (11), 33-68.

Wilson, M. L. (1954). Land Problems and Policies, V. Webster Johnson and Raleigh Barlowe, American Journal of Agricultural Economics, 36(2), 348-350.

\section{Book}

Abdullah, N. (1985). Melayu dan Tanah: Tumpuan khusus kepada Tanah Simpanan Melayu. Kuala Lumpur: Media Intelek Sdn. Bhd.

Adil, B. (1972). Sejarah Pahang. Kuala Lumpur: Dewan Bahasa dan Pustaka.

Anderson, J. (1965). Political and Commercial Considerations Relative to the Malayan Peninsula and the British Settlements in the Straits of Malacca. Singapore.

Gopinath, A. (1993). Sejarah Politik Pahang 1880-1935. Kuala Lumpur: Dewan Bahasa dan Pustaka.

Great Britain. (1843). Parliamentary Papers: 1780-1849, Vol. 36. The Ohio State University: H.M. Stationery Office.

Gullick, J. M. (1965). Indigenous Political Systems of Western Malaya. University of London: Athlone Press.

Haron, N. (1997). Pemilikan dan Pentadbiran Tanah Adat 1800 - 1960. Selangor: Universiti Kebangsaan Malaysia. 
INTERNATIONAL JOURNAL OF ACADEMIC RESEARCH IN BUSINESS AND SOCIAL SCIENCES

Vol. 10, No. 6, June, 2020, E-ISSN: 2222-6990 @ 2020 HRMARS

Karim, A. A. (2012). Rona-rona Pengembaraan, Peristiwa dan Pembangunan di Pahang, dlm Kapitel Kedua: Invigorate Sejarah Pahang dari tahun 1889-1952. Kuantan: Inderapura Printing Company Sdn. Bhd.

Muttalib, J. A. (1972). Pemberontakan Pahang 1891 - 1895. Kelantan: Pustaka Aman Press.

Monograf Sejarah dan Kebudayaan Negeri Pahang. (1982). Pekan: Pahang State Museum Board.

Wong, D. (1975). Tenure and land dealings in the Malay States. Singapore: Singapore University.

Technical and Research Reports (often with corporate authors):

Hagen, V. \& Wolfgang, V. (1908). Draft of Quetzal Quest (about land system). England: William Brendon \& Son, Ltd., Plymouth.

Suhakam. (2015). Report of the National Inquiry into the land rights of indigenous peoples. Kuala Lumpur: National Library of Malaysia. 